\title{
ENHANCEMENT OF FLEXURAL PERFORMANCES THROUGH FRP HYBRIDIZATION WITH HIGH-MODULUS TYPE CARBON FIBERS
}

\author{
Zhishen WU1 ${ }^{1}$, Kouji SAKAMOTO ${ }^{2}$, Kentaro IWASHITA ${ }^{3}$ and Akira KOBAYASHI ${ }^{4}$ \\ ${ }^{1}$ Member of JSCE, Professor, Dept. of Urban and Civil Eng., Ibaraki University \\ (4-12-1, Nakanarusawa-cho, Hitachi-shi, Ibaraki 316-8511) \\ E-mail:zswu@mx.ibaraki.ac.jp \\ ${ }^{2}$ Member of JSCE, Nittetsu Anti-Corrosion Co., Ltd. \\ (12-1-3, higashicyuo, kisaradu-shi, Chiba 292-0057) \\ E-mail: sakamoto-k@ntac.co.jp \\ ${ }^{3}$ Member of JSCE, Researcher, Dept. of Urban and Civil Eng., Ibaraki University \\ (4-12-1, Nakanarusawa-cho, Hitachi-shi, Ibaraki 316-8511) \\ E-mail:iwak@mx.ibaraki.ac.jp \\ ${ }^{4}$ Member of JSCE, Nippon steel Composite Co., Ltd. \\ (Ohara bldg. 3-8, Nihonbashikobuna-cho, Chuo-ku, Tokyo 103-0024) \\ E-mail: a-kobayashi@nick.co.jp
}

\begin{abstract}
The purpose of this study is to investigate the flexural strengthening effects of RC beams with hybrid FRP sheets consisting of high-modulus type continuous carbon fibers. Based on a preliminary hybrid design following mixture rules for the hybridization of high strength and high modulus types of carbon fibers, the hybrid fiber sheets are used to strengthen RC beams. Throughout a series of investigations of beam specimens under three-point bending, the hybrid fiber sheets consisting of high-modulus type carbon fibers as an externally bonded reinforcement can effectively enhance the mechanical properties of RC structures. And serviceability performances of structures such as cracking resistance, stiffness and steel yielding load etc., especially, can be enhanced. Moreover, through a rational design of hybrid fiber sheets, the stress drops due to the gradual ruptures of fibers are controlled and sufficient ductility is achieved by avoiding premature debonding. Finally, some indices for evaluating the strengthening effects of hybrid fiber sheets and the optimum mixture are also suggested and discussed.
\end{abstract}

Key Words : FRP sheets, hybrid, flexural strengthening, high-modulus type carbon fibers

\section{INTRODUCTION}

The deterioration of infrastructures is now becoming a severe social problem for many countries. It is, therefore, urgent that some methods be developed to effectively strengthen and rehabilitate these deteriorated/deteriorating structures. Nowadays, fiber reinforced polymer (FRP) sheets, especially carbon fiber reinforced polymer (CFRP) as external reinforcements, have been increasingly applied in repairing, strengthening and upgrading the deteriorated/deteriorating civil infrastructures since FRP sheets are characterized by high strength and stiffness to weight ratios, high resistance against chemical corrosion, low density and other advantages. In comparison with the traditional strengthening methods, such as the steel plate bonding, overlaying and jacking methods, the external bonding of FRP sheets represents a more applicable and effective technology. This competitive advantage is largely attributed to the beneficial properties of FRP sheets, which include ease of operation and tremendous design flexibility as well as the properties addressed above. Unfortunately, the premature debonding of FRP sheets, which occurs before tensile failure, is a serious problem for the FRP strengthening technique. Moreover, for structures strengthened with FRP sheets consisting merely of a single type of fiber sheet, their serviceability, such as the stiffness, steel yielding load, and crack resistance, cannot be markedly improved. To address these problems, the authors had developed hybrid FRP sheets consisting of several types of fibers of different excellent properties and investigated their mechanical proper- 
ties. Furthermore, several indices, such as the load drop due to the rupture of high modulus and/or high strength fibers, were proposed to evaluate the mechanical properties of hybrid FRP sheets. It was experimentally confirmed that integrative performances including tensile strength, stiffness, and ductility can be thoroughly upgraded through hybridizing high modulus fibers, high strength fibers, and high ductility fibers ${ }^{1)}$. In this study, the strengthening effect of proposed hybrid FRP sheets for concrete structures is experimentally investigated to confirm the previously proposed design and control hybrid indices. Specimens of RC beam strengthened with hybrid FRP sheets are subjected to a 3-point bending.

\section{FANDAMENTAL INVESTIGATION OF HYBRID FRP COMPOSITES}

\section{(1) Concept of hybrid FRP reinforcement}

Based on our previous investigations of the mechanical behaviors of hybrid FRP sheets, the following schematic stress-strain relationship is proposed as shown in Fig. 1. A high stiffness can be obtained, larger even than that of steel, through hybridizing some high-modulus fibers such as high-modulus carbon fibers. Similarly, high strength and ductility can be obtained through hybridizing some high-strength and high-ductility fibers. At $\varepsilon_{\mathrm{y} 0}$, the lower bound rupture strain of the high-modulus fibers, the stress-strain curve begins to become non-linear due to the fracture initiation of the high-modulus fibers. Afterward, the high modulus fibers rupture at their final strain, $\varepsilon_{\mathrm{y}}$, which results in some sudden load drops as shown in Fig. 1. It is this sequential and distributed multi-damage process that contributes to the post-peak ductility of the hybrid composite. The ultimate failure occurs at the rupture strain $\varepsilon_{\mathrm{m}}$ of the high strength fibers. Without polymeric fibers, the hybrid FRP composites with high modulus and high-strength carbon fiber sheets can provide an enhanced initial stiffness, the desired ultimate strength and a sufficient ductility. Moreover, the drop in stress due to the gradual rupture of high modulus fibers was experimentally found to decrease with the increase in remaining fibers, and the usage of PBO (Poly-p-phenylene-benzobisoxazole) fibers and/or Dyneema (polyethylene) fibers was characterized by a superior energy absorption capacity which could lower the value of the drop in stress ${ }^{1)}$. Therefore, the hybridization should meet the following requirements:

1) The remaining fibers can carry the load transferred from the ruptured fibers.

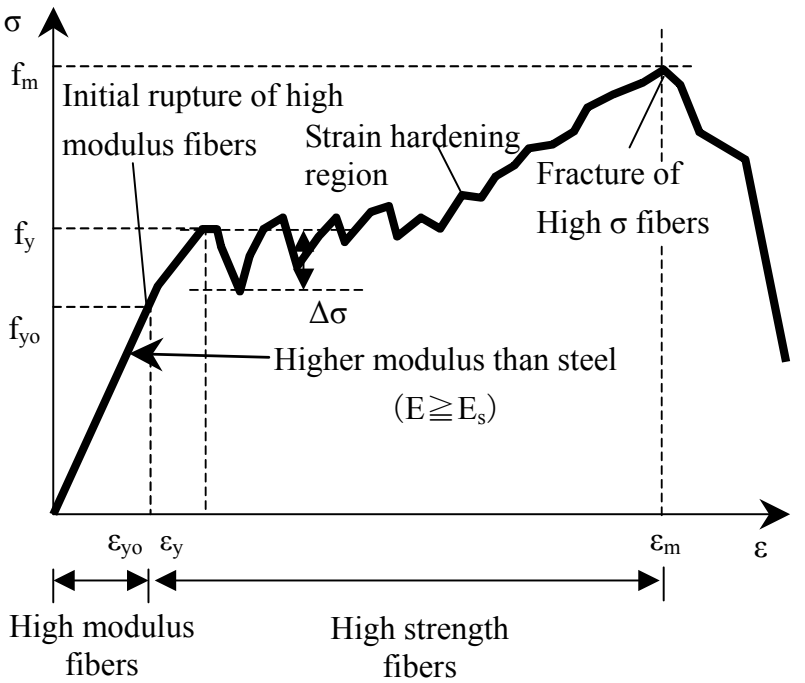

$\mathrm{f}_{\mathrm{y} 0}$ : Initial rupture strength of high modulus fibers $f_{y}$ : Ultimate strength of high modulus fibers $\mathrm{f}_{\mathrm{m}}$ : Maximum strength of high modulus fibers $\varepsilon_{\mathrm{y} 0}$ : Initial rupture strain of high modulus fibers $\varepsilon_{\mathrm{y}}$ : Ultimate strain of high modulus fibers $\varepsilon_{\mathrm{m}}$ : Strain at maximum strength

Fig.1 Principle of tensile behavior of hybrid fiber reinforcement.

2) The momentary drop in stress due to the rupture of one fiber type can be suppressed as much as possible by the remaining fibers.

The tensile modulus and strength of hybrid fiber sheets can be calculated according to mixture law of hybrid composites ${ }^{2}$. In the previous study, the control index of load drop due to the impact energy dissipation at the rupture of high modulus fibers was suggested ${ }^{1)}$. This detail is explained in $\mathbf{2 . 4}$.

\section{(2) Preliminary hybrid design following low of mixture}

According to mixture law of hybrid composites, the stress $\sigma_{\mathrm{ave}}$ or load-strain $\mathrm{P}_{\mathrm{ave}}-\varepsilon$ relationships and the elastic modulus $\mathrm{E}_{\mathrm{ave}}$ of hybrid composites can be given as,

$$
\begin{aligned}
& \sigma_{\mathrm{L}}=\varepsilon\left(\mathrm{E}_{\mathrm{m}} \mathrm{A}_{\mathrm{m}}+\mathrm{E}_{\mathrm{s}} \mathrm{A}_{\mathrm{s}}\right) / \mathrm{A} \\
& \mathrm{E}_{\mathrm{L}}=\left(\mathrm{E}_{\mathrm{m}} \mathrm{A}_{\mathrm{m}}+\mathrm{E}_{\mathrm{s}} \mathrm{A}_{\mathrm{s}}\right) / \mathrm{A}
\end{aligned}
$$

where $E_{m}, E_{f}$, and $A_{m}, A_{f}$ are the elastic moduli and cross-sectional areas of high-modulus, and highstrength fiber sheets, respectively. $\mathrm{A}$ is the total cross-sectional area of the fiber sheets $\left(A=A_{m}+A_{s}\right)$. Fig.2 shows the design principle of the hybrid fiber reinforcement. In addition, detailed observation of FRP sheets after final failure is needed, because the Bernoulli-Euler hypothesis is one of the preconditions of mixture law. 
(3) Tensile behavior of hybrid FRP sheets

a) Before initiation of high-modulus carbon fiber rupture

The tensile strength $\sigma_{\mathrm{I}}$ and elastic modulus $\mathrm{E}_{\mathrm{I}}$ of the hybrid composites before the initiation of high-modulus carbon fibers rupture can be represented by the following equations.

$$
\begin{aligned}
& \sigma_{\mathrm{l}}=\varepsilon\left(\mathrm{E}_{\mathrm{m}} \mathrm{A}_{\mathrm{m}}+\mathrm{E}_{\mathrm{s}} \mathrm{A}_{\mathrm{s}}\right) / \mathrm{A} \\
& \mathrm{E}_{\mathrm{l}}=\left(\mathrm{E}_{\mathrm{m}} \mathrm{A}_{\mathrm{m}}+\mathrm{E}_{\mathrm{s}} \mathrm{A}_{\mathrm{s}}\right) / \mathrm{A}
\end{aligned}
$$

\section{b) From initiation of high-modulus carbon fibers rupture to final rupture}

Generally, the applied load drops immediately upon the initial rupture of the high-modulus carbon fiber sheets, but the drop in load can be effectively suppressed through increasing the volume fraction of the remaining FRP sheets after the rupture of the high modulus fibers and/or through using PBO or Dyneema fibers that are characterized by better energy absorption capacity as the remaining fiber sheets in the hybrid FRP sheets.

c) From high-modulus carbon fibers final rupture to high-strength carbon fibers rupture

The tensile strength $\sigma_{\text {III }}$ and elastic modulus $\mathrm{E}_{\text {III }}$ of the hybrid composites before the initiation of high-modulus carbon fibers rupture can be represented by the following equations.

$$
\begin{aligned}
\sigma_{\mathrm{III}} & =\varepsilon \mathrm{E}_{\mathrm{s}} \\
\mathrm{E}_{\mathrm{III}} & =\mathrm{E}_{\mathrm{s}}
\end{aligned}
$$

These equations can be used when there is neither fracture nor slack in the remaining fibers upon the rupture of the high modulus fibers.

(4) Index of load drop control at the high-modulus carbon fibers rupture

In our previous study ${ }^{1)}, \lambda_{1}\left(=\sigma_{\mathrm{dm}} / \mathrm{f}_{\mathrm{y}}^{\prime}\right)$ and $\lambda_{2}$ $\left(=\sigma_{\mathrm{dm}} / \mathrm{f}_{\mathrm{m}}{ }_{\mathrm{m}}\right)$ were suggested as indices of load drop control upon the initial rupture of high modulus fiber sheets. Then, $\sigma_{\mathrm{dm}}$ is the value of the load drop upon rupture of the high modulus fiber sheets, $\mathrm{f}_{\mathrm{y}}$ is the tensile stress just before the rupture of the high modulus fiber sheets, and $\mathrm{f}_{\mathrm{m}}{ }_{\mathrm{m}}$ is the tensile strength of the high strength fiber sheets.

\section{EXPERIMENTAL PROGRAM}

\section{(1) Details of RC beams}

The specimen of reinforced concrete beam is schematically shown in Fig.3 with a dimension of $2.1 \mathrm{~m}$ in span, $150 \mathrm{~mm}$ in width, and $200 \mathrm{~mm}$ in height. Four steel rebars of $13 \mathrm{~mm}$ in diameter were distributed in the specimen as tensile and compressive reinforcements with a reinforcement ratio of $1.8 \%$. The tensile properties of concrete, steel rebar, and epoxy resin are shown in Table 1. The distance between two supports is $1800 \mathrm{~mm}$ and the bonding length of FRP sheets is $1700 \mathrm{~mm}$. The flexural and

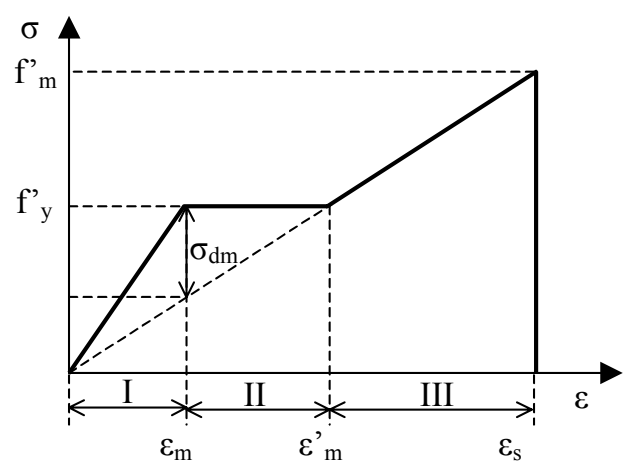

$\mathrm{f}_{\mathrm{y}}$ : Ultimate strength of high modulus fibers

$\mathrm{f}_{\mathrm{m}}$ : Ultimate strength of high strength fibers

$\sigma_{\mathrm{dm}}$ : Amount of decreased stress at initial rupture of high modulus fibers

$\varepsilon_{\mathrm{m}}$ : Initial rupture strain of high modulus fibers

$\varepsilon_{\mathrm{m}}^{\prime}$ : Ultimate strain of high modulus fibers

$\varepsilon_{\mathrm{s}}$ : Strain at maximum strength

Fig.2 Principle of designed tensile behavior of hybrid fiber reinforcement.

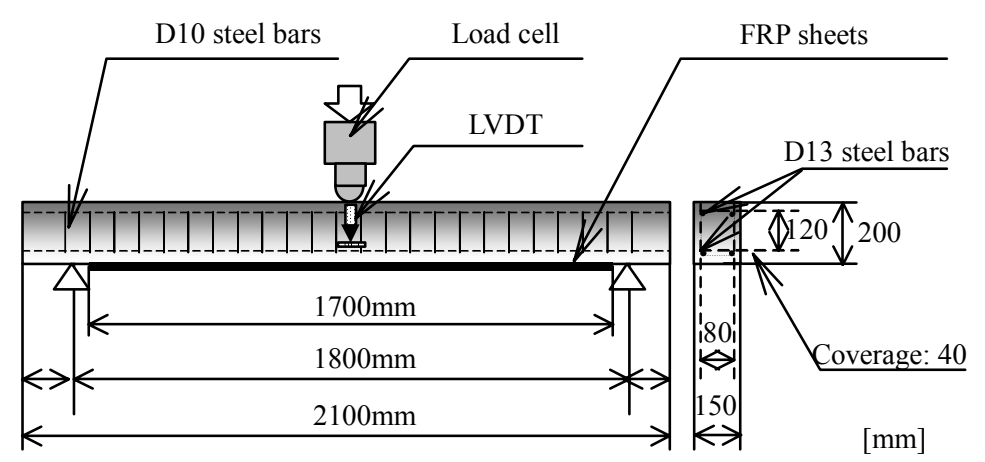

Fig.3 Dimension of strengthened RC beam. 
Table 1 Properties of materials.

\begin{tabular}{|c|c|c|}
\hline Materials & Properties & Value \\
\hline \multirow{3}{*}{ Concrete } & Compressive strength $(\mathrm{MPa})$ & 50.3 \\
\cline { 2 - 3 } & Compressive modulus $(\mathrm{GPa})$ & 33.1 \\
\cline { 2 - 3 } & Poison's ratio & 0.13 \\
\hline $\begin{array}{c}\text { Steel bars } \\
\text { (SD295A, D13) }\end{array}$ & Tensile yielding strength $(\mathrm{MPa})$ & 358 \\
\cline { 2 - 3 } & Tensile rupture strength $(\mathrm{MPa})$ & 504 \\
\hline \multirow{2}{*}{ Epoxy resin } & Tensile strength $(\mathrm{MPa})$ & 51.9 \\
\cline { 2 - 3 } & Tensile modulus $(\mathrm{GPa})$ & 3.43 \\
\hline
\end{tabular}

shear maximum loads of this $\mathrm{RC}$ beam were calculated according to JSCE guidelines ${ }^{3)}$ to be $42 \mathrm{kN}$ and $141 \mathrm{kN}$, respectively. These beams with enough shear capacity are mainly used to investigate flexural performances of $\mathrm{RC}$ beams strengthened with hybrid fiber sheets.

\section{(2) Concrete surface treatment and strengthening with hybrid FRP sheets}

Before the bonding of the FRP sheet, the concrete surface was treated with a diamond sander, cleaned with acetone, and then painted with epoxy primer whose weight per unit area was $0.4 \mathrm{~kg} / \mathrm{m}^{2}$. After the curing of the epoxy-painted concrete beam for about 12 hours, FRP sheets with a dimension of $150 \mathrm{~mm}$ in width and $1700 \mathrm{~mm}$ in length were impregnated with epoxy resin and bonded to the concrete surface. Before testing, the strengthened concrete specimens were cured for one week in the open air at room temperature for a firm bonding of the hybrid FRP sheets to the concrete beam.

\section{(3) Layered constitution of hybrid FRP sheets}

Carbon fiber sheets (C7) were used as high modulus fiber sheets, and carbon fiber sheets (C1) and PBO fiber sheets (P) were used as high strength fiber sheets. The experimental parameters including type and volume-fraction of various types of fiber sheets are described as follows:

1) Strengthening with a single kind of fiber sheets.

2) Strengthening with hybrid FRP sheets by using two kinds of fiber sheets whose hybrid ratio is $1: 1$.

3) Strengthening with hybrid FRP sheets whose constitutions are 1:2,1:3, and so on.

Table 2 shows the types of hybrid FRP sheets that are used as external reinforcements for the concrete beam. The tensile modulus and strength are calculated according to Eq.(1) and Eq.(2); these values are shown in Table 3. Then, the average tensile strengths obtained from tensile tests are shown in Table 4; they are used to calculate the elastic modulus of hybrid fiber sheets. The name of specimen represents types and layers of fiber sheets that
Table 2 Designation of beams.

\begin{tabular}{|c|c|c|}
\hline Beams & Kinds and layers of fiber sheets & Total layer \\
\hline NR & Reference without carbon fiber sheets & 0 \\
\hline $\mathrm{C} 1$ & $1-\mathrm{HSC}^{*}$ sheets & 1 \\
\hline $2 \mathrm{C} 1$ & 2-HSC sheets & 2 \\
\hline $3 \mathrm{C} 1$ & 3-HSC sheets & 3 \\
\hline $\mathrm{C} 1 \mathrm{C} 7$ & $1-\mathrm{HMC}^{* *}$ sheets/1-HSC sheets & 2 \\
\hline $1.5 \mathrm{C} 1 \mathrm{C} 7$ & 1-HMC sheets/1.5-HSC sheets & 2.5 \\
\hline $2 \mathrm{C} 1 \mathrm{C} 7$ & 1-HMC sheets/2-HSC sheets & 3 \\
\hline $2.5 \mathrm{C} 1 \mathrm{C} 7$ & 1-HMC sheets/2.5-HSC sheets & 3.5 \\
\hline $\mathrm{P}$ & 1-PBO fiber sheets & 1 \\
\hline $2 \mathrm{P}$ & 2-PBO fiber sheets & 2 \\
\hline $3 \mathrm{P}$ & 3-PBO fiber sheets & 3 \\
\hline PC7 & 1-HMC sheets/1-PBO fiber sheets & 2 \\
\hline $1.5 \mathrm{PC} 7$ & 1-HMC sheets/1.5-PBO fiber sheets & 2.5 \\
\hline $2 \mathrm{PC} 7$ & 1-HMC sheets/2-PBO fiber sheets & 3 \\
\hline $2.5 \mathrm{PC} 7$ & 1-HMC sheets/2.5-PBO fiber sheets & 3.5 \\
\hline
\end{tabular}

* HSC means high strength carbon fiber sheets

**HMC means high modulus carbon fiber sheets

Table 3 Areas, modulus and unit stiffness of hybrid fiber sheets.

\begin{tabular}{|c|c|c|c|c|c|}
\hline Beam & $\begin{array}{c}\text { Area of } \\
\text { FRP } \\
\left(\mathrm{mm}^{2}\right)\end{array}$ & $\begin{array}{c}\text { Modulus of } \\
\text { FRP sheets } \\
\left(\mathrm{N} / \mathrm{mm}^{2}\right)\end{array}$ & Beam & $\begin{array}{c}\text { Area of } \\
\text { FRP } \\
\left(\mathrm{mm}^{2}\right)\end{array}$ & $\begin{array}{l}\text { Modulus of } \\
\text { FRP sheets } \\
\left(\mathrm{N} / \mathrm{mm}^{2}\right)\end{array}$ \\
\hline NR & 0 & 0 & & & \\
\hline $\mathrm{C} 1$ & 16.65 & \multirow{3}{*}{$2.3 \times 10^{5}$} & $\mathrm{P}$ & 19.20 & \multirow{3}{*}{$2.4 \times 10^{5}$} \\
\hline $2 \mathrm{Cl}$ & 33.30 & & $2 \mathrm{P}$ & 38.40 & \\
\hline $3 \mathrm{C} 1$ & 49.95 & & $3 \mathrm{P}$ & 57.60 & \\
\hline $\mathrm{C} 1 \mathrm{C} 7$ & 38.10 & $4.05 \times 10^{5}$ & PC7 & 40.65 & $3.98 \times 10^{5}$ \\
\hline $1.5 \mathrm{C} 1 \mathrm{C} 7$ & 46.43 & $3.73 \times 10^{5}$ & $1.5 \mathrm{PC} 7$ & 50.25 & $3.68 \times 10^{5}$ \\
\hline $2 \mathrm{C} 1 \mathrm{C} 7$ & 54.75 & $3.51 \times 10^{5}$ & $2 \mathrm{PC} 7$ & 59.85 & $3.48 \times 10^{5}$ \\
\hline $2.5 \mathrm{C} 1 \mathrm{C} 7$ & 63.08 & $3.35 \times 10^{5}$ & $2.5 \mathrm{PC} 7$ & 69.45 & $3.33 \times 10^{5}$ \\
\hline
\end{tabular}

are involved in hybrid fiber sheets. Then, the unit weight is defined as $200 \mathrm{~g} / \mathrm{m}^{2} / 1$ layer. " 1.5 layers" means a 1 layer sheet plus a half-width 1 layer sheet.

\section{(4) Index of load drop control at the high-modulus carbon fibers rupture of specimens strength- ened with hybrid FRP sheets}

Table 5 shows a summary of the control indices $\lambda_{1}\left(=\sigma_{\mathrm{dm}} / \mathrm{f}_{\mathrm{y}}^{\prime}\right)$ and $\lambda_{2}\left(=\sigma_{\mathrm{dm}} / \mathrm{f}^{\prime} \mathrm{m}\right)$ calculated from the above equations. It was found that after the initial rupture of the high modulus fiber sheets the control indices decrease with increasing the layers of remaining fiber sheets. In this study, following $\Lambda_{1}$ and $\Lambda_{2}$ are defined as indices to evaluate the load drop of an RC beam strengthened with hybrid fiber sheets occurring at the initial rupture of the high modulus fiber sheets. These indices are calculated by the 
Table 4 Summary of mechanical properties of different fiber sheets.

\begin{tabular}{|c|c|c|c|c|}
\hline Properties & No. & HMC sheets & HSC sheets & PBO fiber sheets \\
\hline \multirow{11}{*}{$\begin{array}{l}\text { Measured tensile } \\
\text { strength }\left(\mathrm{N} / \mathrm{mm}^{2}\right)\end{array}$} & 1 & 2763 & 4234 & 4418 \\
\hline & 2 & 2740 & 4225 & 4073 \\
\hline & 3 & 2394 & 4040 & 4500 \\
\hline & 4 & 2459 & 4020 & 4139 \\
\hline & 5 & 2507 & 4277 & 3875 \\
\hline & 6 & 2874 & 4134 & 4361 \\
\hline & 7 & 2339 & 4346 & 4185 \\
\hline & 8 & 2614 & 4049 & 4148 \\
\hline & 9 & 2825 & 4344 & 4547 \\
\hline & 10 & $*$ & 4654 & $*$ \\
\hline & Average & 2613 & 4232 & 4250 \\
\hline \multicolumn{2}{|c|}{ Guaranteed tensile strength(N/mm²) } & 1900 & 3400 & 3500 \\
\hline \multicolumn{2}{|c|}{ Nominal elastic modulus $\left(\mathrm{kN} / \mathrm{mm}^{2}\right)$} & 540 & 230 & 240 \\
\hline \multicolumn{2}{|c|}{ Nominal rupture strain $(\%)$} & 0.35 & 1.48 & 1.46 \\
\hline \multicolumn{2}{|c|}{ Nominal thickness (mm) } & 0.143 & 0.111 & 0.128 \\
\hline
\end{tabular}

Table 5 Summary of mechanical properties of different fiber sheets.

\begin{tabular}{|c|c|c|c|c|c|c|}
\hline \multicolumn{2}{|c|}{ Layer } & \multirow{2}{*}{$\begin{array}{c}\text { Tensile stress of HMC } \\
\text { sheets just before initial } \\
\text { rupture } \mathrm{f}_{\mathrm{y}}\left(\mathrm{N} / \mathrm{mm}^{2}\right)\end{array}$} & \multirow{2}{*}{$\begin{array}{c}\text { Credible tensile stress of } \mathrm{HMC} \\
\text { sheets just after initial rupture } \\
\qquad \sigma_{\mathrm{dm}}\left(\mathrm{N} / \mathrm{mm}^{2}\right)\end{array}$} & \multirow{2}{*}{$\begin{array}{c}\text { Tensile strength of } \\
\text { HSC sheets } \\
\mathrm{f}_{\mathrm{m}}\left(\mathrm{N} / \mathrm{mm}^{2}\right)\end{array}$} & \multirow{2}{*}{$\begin{array}{c}\lambda_{1}=\sigma_{\mathrm{dm}} / \mathrm{f}_{\mathrm{y}} \\
(\%)\end{array}$} & \multirow{2}{*}{$\begin{array}{c}\lambda_{2}=\sigma_{\mathrm{dm}} / \mathrm{f}_{\mathrm{m}} \\
(\%)\end{array}$} \\
\hline $\begin{array}{l}\text { HMC } \\
\text { sheets }\end{array}$ & $\begin{array}{c}\text { HSC } \\
\text { sheets }\end{array}$ & & & & & \\
\hline \multirow{5}{*}{1} & 1 & 1957 & 845 & 4232 & 43 & 20 \\
\hline & 1.5 & 1806 & 693 & 4232 & 38 & 16 \\
\hline & 2 & 1701 & 588 & 4232 & 35 & 14 \\
\hline & 2.5 & 1623 & 510 & 4232 & 31 & 12 \\
\hline & 3 & 1564 & 451 & 4232 & 29 & 11 \\
\hline
\end{tabular}

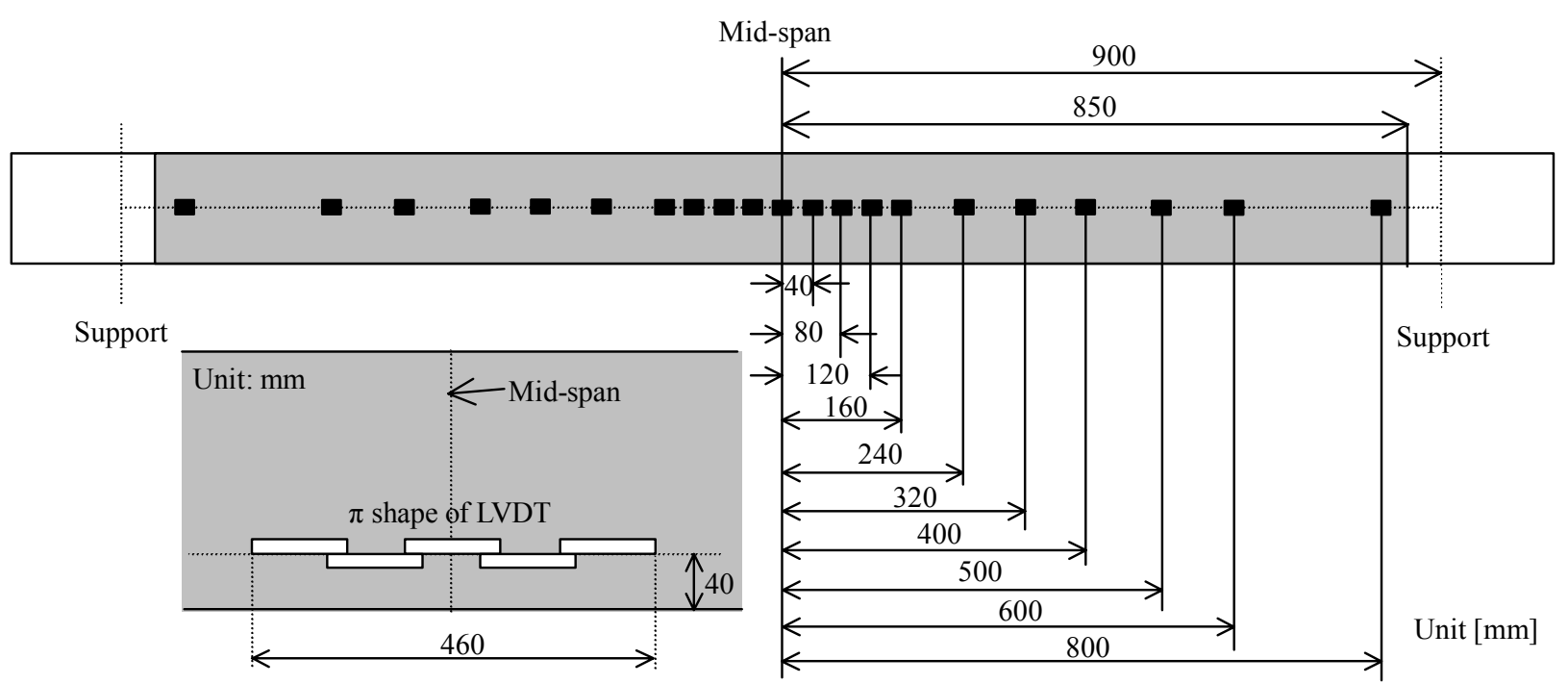

Fig.4 Details of measurements.

following equations.

$$
\begin{aligned}
& \Lambda_{1}=\Delta \mathrm{P} / \mathrm{P}_{\mathrm{y}} \\
& \Lambda_{2}=\Delta \mathrm{P} / \mathrm{P}_{\mathrm{m}}
\end{aligned}
$$

\section{(5) Details of measurement}

Three strain gauges were attached to the tensile steel rebar to measure its strain and detect its yielding. 21 strain gauges were attached to the FRP surface to investigate the FRP strain distribution as 
Table 6 Summary of experimental results.

\begin{tabular}{|c|c|c|c|c|c|}
\hline Beam & $\begin{array}{c}\text { Cracking } \\
\text { load } \\
(\mathrm{kN})\end{array}$ & $\begin{array}{c}\text { Steel } \\
\text { yielding } \\
\text { load (kN) }\end{array}$ & $\begin{array}{c}\text { Maximum } \\
\text { load }(\mathrm{kN})\end{array}$ & $\begin{array}{c}\text { Displacemen } \\
\text { t at the } \\
\text { maximum } \\
\text { load (mm) }\end{array}$ & $\begin{array}{c}\text { Failure } \\
\text { mode }\end{array}$ \\
\hline $\mathrm{NR}$ & 12.80 & 35.47 & 42.42 & 13.10 & $\mathrm{~A}$ \\
\hline $\mathrm{C} 1$ & 9.10 & 40.97 & 63.38 & 20.90 & $\mathrm{~B}$ \\
\hline 2C1 & 12.76 & 49.72 & 81.17 & 20.25 & $\mathrm{C}$ \\
\hline 3C1 & 19.05 & 56.91 & 94.95 & 14.55 & $\mathrm{~B}$ \\
\hline $\mathrm{C} 1 \mathrm{C} 7$ & 9.23 & 52.18 & 71.71 & 17.89 & $\mathrm{~F}$ \\
\hline 1.5C1C7 & 11.15 & 53.14 & 77.12 & 16.41 & $\mathrm{D}$ \\
\hline 2C1C7 & 13.00 & 61.50 & 86.53 & 19.21 & $\mathrm{C}$ \\
\hline $2.5 \mathrm{C} 1 \mathrm{C} 7$ & 13.03 & 62.55 & 96.05 & 25.84 & $\mathrm{~B}$ \\
\hline $\mathrm{P}$ & 13.50 & 41.07 & 68.08 & 17.06 & $\mathrm{E}$ \\
\hline 2P & 13.60 & 46.18 & 87.15 & 19.18 & $\mathrm{C}$ \\
\hline 3P & 19.05 & 55.10 & 97.58 & 19.03 & $\mathrm{~B}$ \\
\hline PC7 & 13.06 & 50.07 & 78.13 & 15.54 & $\mathrm{~F}$ \\
\hline 1.5PC7 & 18.10 & 58.06 & 79.14 & 16.17 & $\mathrm{D}$ \\
\hline 2PC7 & 13.15 & 61.07 & 94.01 & 24.97 & $\mathrm{C}$ \\
\hline $2.5 \mathrm{PC} 7$ & 19.08 & 66.18 & 95.07 & 17.42 & $\mathrm{~B}$ \\
\hline
\end{tabular}

shown in Fig.4. Moreover, two LVDTs and five $\pi$-shaped LVDTs were attached to the side surface of the concrete to measure both the deformation at the mid-span and the average crack width.

\section{EXPERIMENTAL RESULTS}

\section{(1) Failure mode}

The cracking load, steel yielding load, maximum load, displacement at maximum load, and failure mode are shown in Table 6. The marks from A to F indicate the situations of the final failure of the corresponding specimen.
A: Concrete crush
B: FRP debonding
C: Balance failure between A and B
D: $C$ failure with partial rupture of FRP sheets
E: FRP rupture
$\mathrm{F}$ : Balance failure between $\mathrm{A}$ and $\mathrm{E}$

Moreover, the steel-yielding load is defined as a load at which the stiffness of the strengthened structure begins to decrease; this is also, the load that corresponds to the first inflexion of the load-displacement curve as shown in Figs.5 (a) to (d).

\section{(2) Discuss about load-displacement relationship}

Observation showed that single-layer $\mathrm{C} 1$ or $\mathrm{P}$ sheets failed in rupture whereas with the increase of FRP amounts, debonding failure was caused from the end of a critical flexural crack hybrid fiber sheets, the failure mode may be shifted from debonding to gradual ruptures and the premature FRP debonding can be avoided and controlled by the FRP hybrid. As demonstrated in Figs.5 (a) to (b), hybrid fiber sheets with a hybridization of the higher modulus type of carbon fiber sheets (C7) can

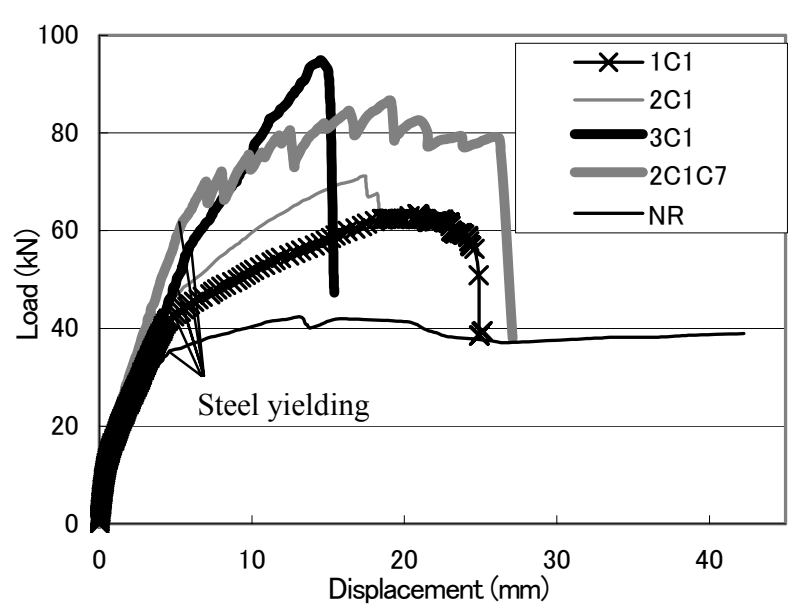

Fig.5 (a) Load-displacement curve (Mainly about C1).

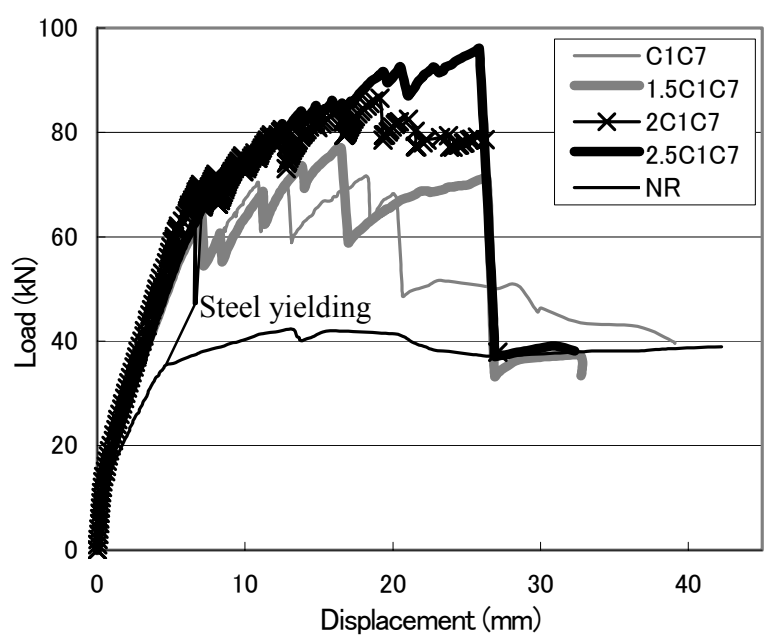

Fig.5 (b) Load-displacement curve (Mainly about C1C7 hybrid sheets).

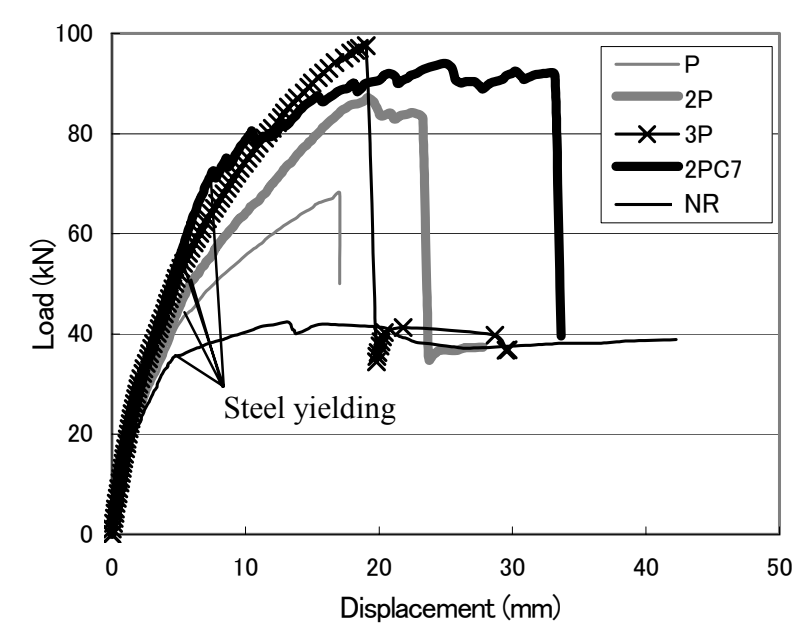

Fig.5 (c) Load-displacement curve (Mainly about P).

achieve a higher initial stiffness. Because the gradual ruptures of fibers prevent the occurrence of FRP debonding, a good ductility can also be achieved. Due to the partial rupture of $\mathrm{C} 7$ in the hybrid fiber sheets, stresses may be redistributed and thus the 


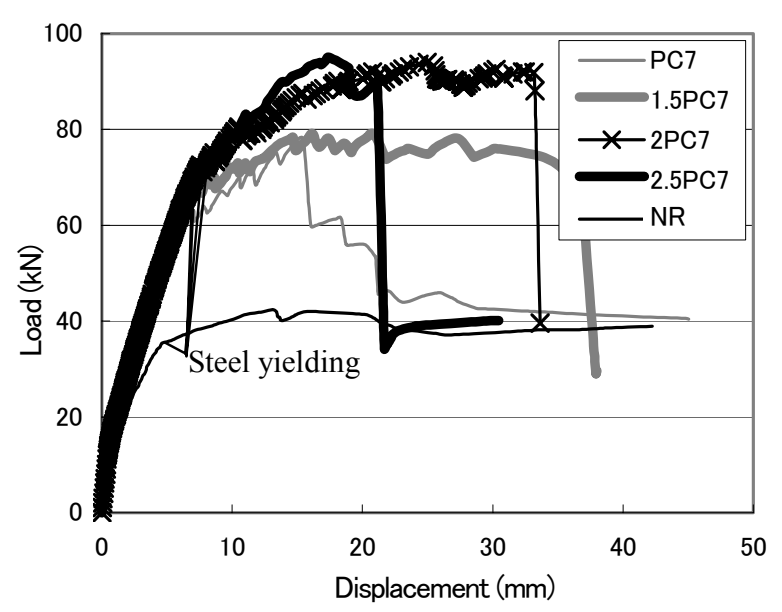

Fig.5 (d) Load-displacement curve (Mainly about PC7 hybrid sheets).

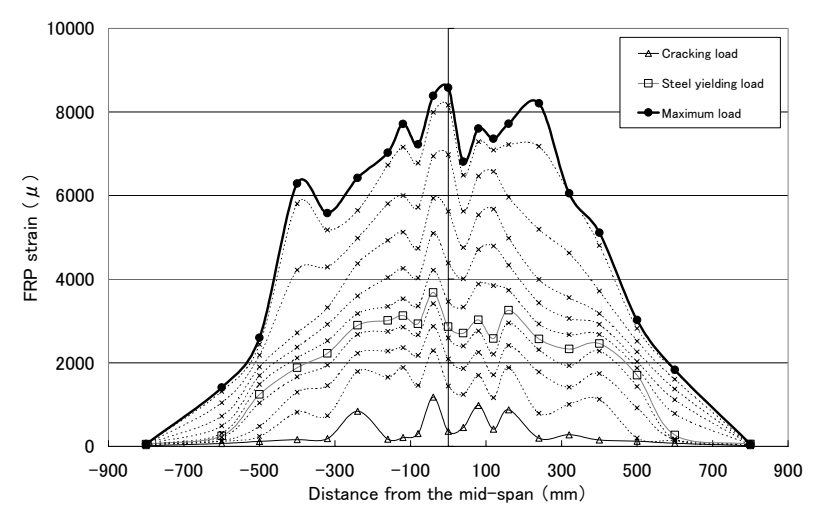

Fig.6 (a) Distribution of FRP strain of 3C1 beam (Debonding failure with partial rupture).

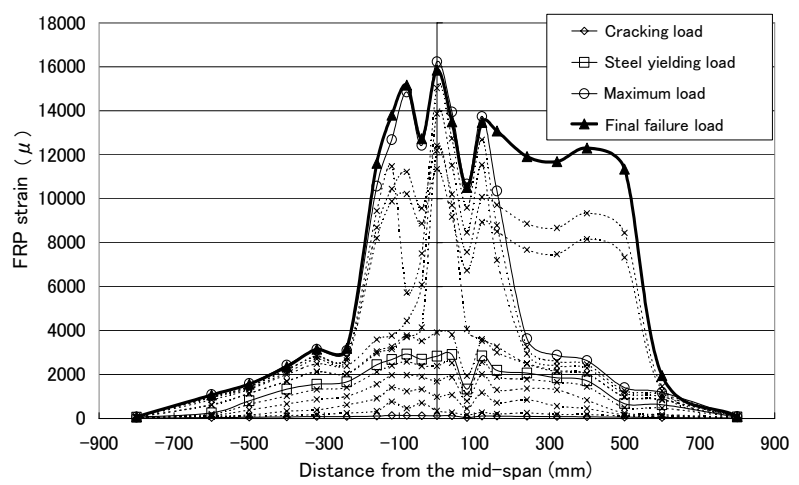

Fig.6 (b) Distribution of FRP strain of $1.5 \mathrm{C} 1 \mathrm{C} 7$ beam (Debonding failure).

interfacial shear stress along the FRP-concrete interface can be relieved, which is helpful to fully utilize the potential of FRP composites and increase their ductility though final failure mode remains unchanged (debonding).

Evaluation indices of the load drop, $\Lambda_{1}$ and $\Lambda_{2}$, are all calculated according to the Eq.(7) and Eq.(8) shown in 3.4 section. $\Lambda_{1}$ and $\Lambda_{2}$ are $18.2 \%$ and $17.0 \%$ for $\mathrm{C} 1 C 7_{2}=20 \%$ ), $13.8 \%$ and $11.3 \%$ for

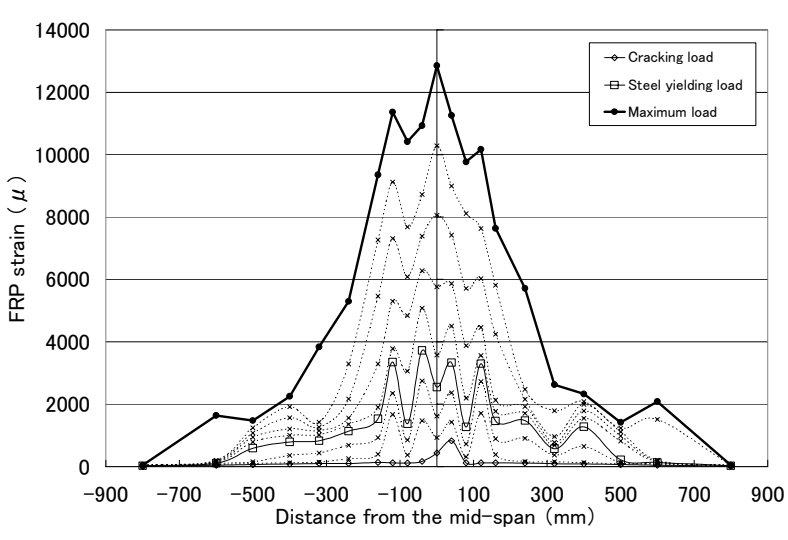

Fig.6 (c) Distribution of FRP strain of $\mathrm{P}$ beam (Rupture failure).

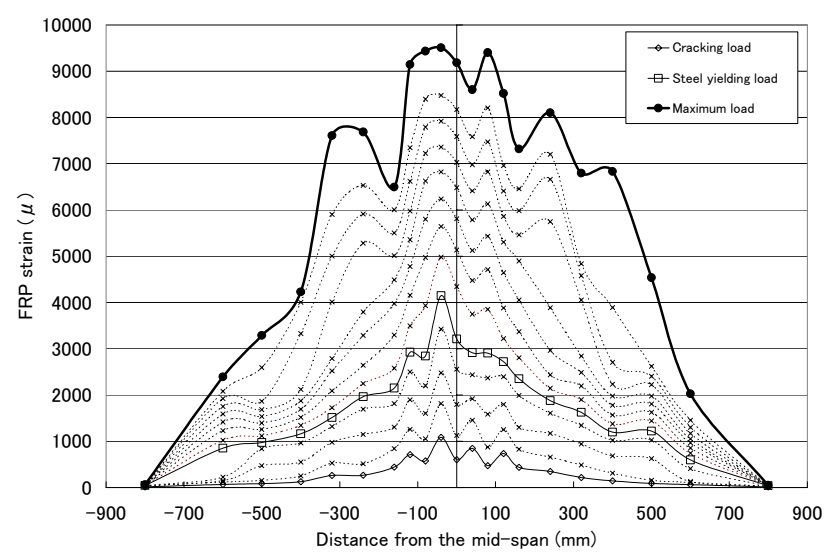

Fig.6 (d) Distribution of FRP strain of 3P beam (Debonding failure).

$1.5 \mathrm{C} 1 \mathrm{C} 7\left(\lambda_{1}=38 \%, \lambda_{2}=16 \%\right), 5.6 \%$ and $4.5 \%$ for $2 \mathrm{ClC} 7\left(\lambda_{1}=35 \%, \lambda_{2}=14 \%\right)$ and $1.2 \%$ and $0.9 \%$ for $2.5 \mathrm{C} 1 \mathrm{C} 7\left(\lambda_{1}=31 \%, \lambda_{2}=12 \%\right)$, respectively. The load drop in load decreased with increasing layers of $\mathrm{C} 1$. The usage of PBO fiber sheets as high strength fiber sheets lowered the load drop value. On the other hand, ductilities, defined as the displacement at the final failure, of specimens with hybrid FRP sheets including PBO fibers as high strength fibers are larger than those consists of other type of fbers. From these results, it is confirmed that the drop in load decreases and ductility increases when the energy absorption capacity of PBO fiber sheets is used.

\section{(3) Distribution of FRP strain}

Figs.6 (a) to (e) demonstrate the distribution of FRP strains with distance from the mid-span under different loading levels. The value of stiffness $\times$ area of FRP of the $1.5 \mathrm{C} 1 \mathrm{C} 7$ beam is nearly the same as that of the $3 \mathrm{C} 1$, but the distributions of the FRP strain are different from each other. In the case of the 3C1 beam, shown in Fig.6 (a), the maximum FRP strains at the maximum load is below $8500 \mu \varepsilon$, which is much smaller than the rupture strain of carbon fibers due to premature debonding failure of FRP sheets. On the other hand, in the case of the 


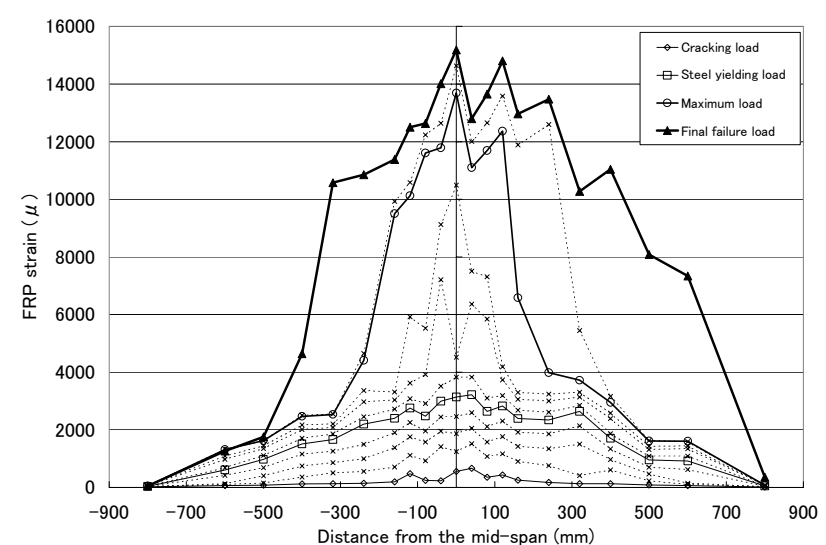

Fig.6 (e) Distribution of FRP strain of 1.5PC7 beam (Debonding failure with partial rupture).

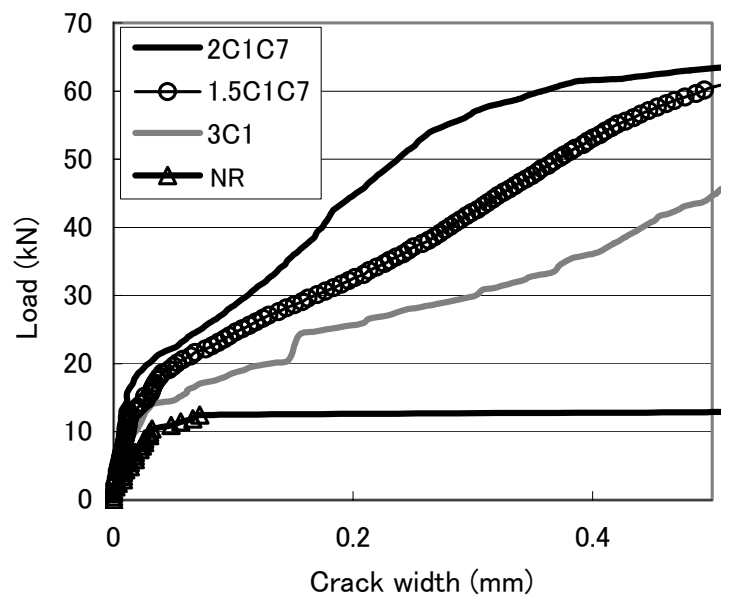

Fig.7 Relationships between load and average crack width.

1.5C1C7 beam, shown in Fig.6 (b), the maximum FRP strains at the maximum load is about $16000 \mu \varepsilon$, which exceeds the rupture strain of the carbon fibers. The same conclusion can be drawn from Figs.6 (c) to (e).

\section{(4) Resistance against initiation of and propaga- tion of cracks}

Fig.7 shows the load-crack width curve for RC beams strengthened with single or hybrid fiber sheets. Comparing the results of the $3 \mathrm{C} 1$ beam and the $1.5 \mathrm{C} 1 \mathrm{C} 7$ beam, the crack width of the $1.5 \mathrm{C} 1 \mathrm{C} 7$ beam is smaller than that of the $\mathrm{C} 1$ beam, which means the propagation of cracks can be effectively suppressed by using high modulus fiber sheets of C7. Moreover, the cracks are more dispersive for the $1.5 \mathrm{C} 1 \mathrm{C} 7$ beam as shown in Fig.8. The crack resistance increases with the increase in high modulus fiber sheets.

\section{(5) Indices of RC beams strengthened with hy- brid FRP sheets}

1) Five indices are suggested to evaluate the strengthening effect of hybrid fiber sheets

2) Steel yielding load (steel yielding load/steel

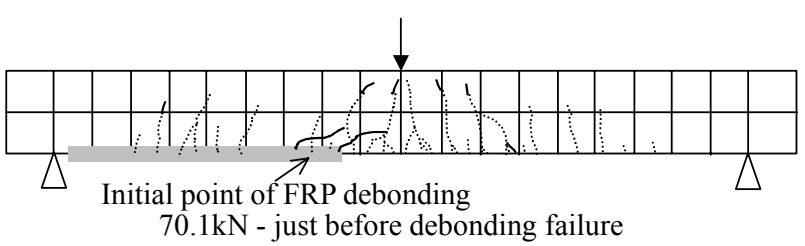

(a) $3 \mathrm{C} 1$ beam.

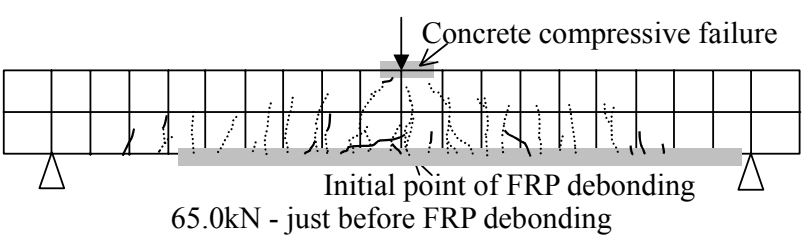

(b) 2C1C7 beam.

Fig.8 Crack distribution of hybrid beams.

Table 7 Evaluation index: steel yielding load measured with strain gauges.

\begin{tabular}{|c|c|c|c|c|c|c|c|}
\hline Beam & $\mathrm{C} 1$ & $2 \mathrm{C} 1$ & $3 \mathrm{C} 1$ & $\mathrm{C} 1 \mathrm{C} 7$ & $1.5 \mathrm{C} 1 \mathrm{C} 7$ & $2 \mathrm{C} 1 \mathrm{C} 7$ & $2.5 \mathrm{C} 1 \mathrm{C} 7$ \\
\hline \hline $\begin{array}{c}\text { Evaluation index } \\
\text { Steel yielding }\end{array}$ & 1.16 & 1.40 & 1.60 & 1.47 & 1.50 & 1.73 & 1.76 \\
\hline $\begin{array}{c}\text { Stiffness, Ex } \\
\text { Thickness, } \mathrm{t} \\
\text { (kN/mm) }\end{array}$ & 25.53 & 51.06 & 76.59 & 102.75 & 115.52 & 128.28 & 141.05 \\
\hline Beam & $\mathrm{P}$ & $2 \mathrm{P}$ & $3 \mathrm{P}$ & $\mathrm{PC} 7$ & $1.5 \mathrm{PC} 7$ & $2 \mathrm{PC} 7$ & $2.5 \mathrm{PC} 7$ \\
\hline \hline $\begin{array}{c}\text { Evaluation index } \\
\text { Steel yielding }\end{array}$ & 1.16 & 1.30 & 1.55 & 1.41 & 1.64 & 1.72 & 1.87 \\
\hline $\begin{array}{c}\text { Stiffness, Ex } \\
\text { Thickness, } \mathrm{t} \\
\text { (kN/mm) }\end{array}$ & 30.72 & 61.44 & 92.16 & 107.94 & 123.30 & 138.66 & 154.02 \\
\hline
\end{tabular}

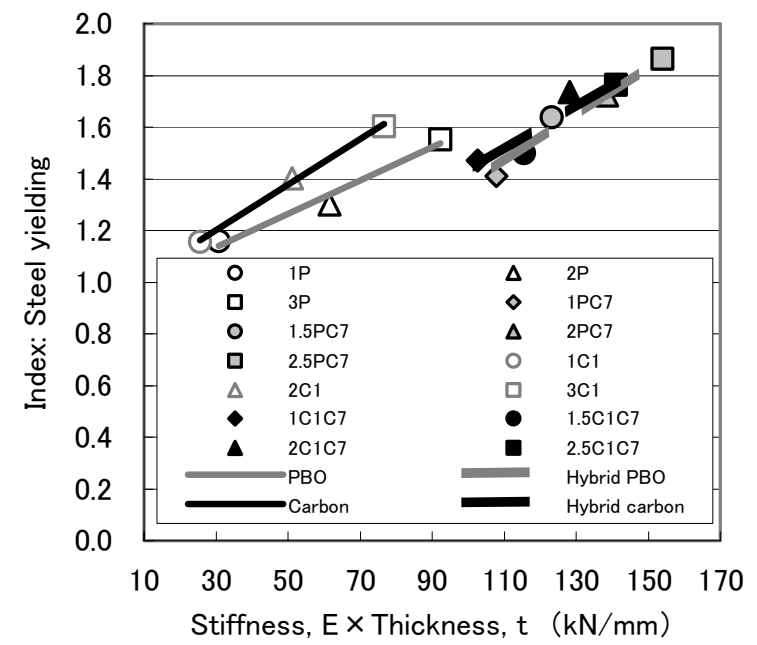

Fig.9 Evaluation index: Steel yielding measured with strain gauges.

yielding load of NR)

3) Maximum load (maximum load/maximum load of NR)

4) Ductility (displacement at the final failure/displacement at steel yielding)

FRP strain (maximum FRP strain/average rupture strain obtained from experiments)

a) Evaluation of yielding load with steel strain

Table 7 and Fig. 9 show the yielding load-stiffness curve for different specimens. This figure shows 
Table 8 Evaluation index: steel yielding load measured with strain gauges.

\begin{tabular}{|c|c|c|c|c|c|c|c|}
\hline Beam & $\mathrm{C} 1$ & $2 \mathrm{C} 1$ & $3 \mathrm{C} 1$ & $\mathrm{C} 1 \mathrm{C} 7$ & $1.5 \mathrm{C} 1 \mathrm{C} 7$ & $2 \mathrm{C} 1 \mathrm{C} 7$ & $2.5 \mathrm{C} 1 \mathrm{C7} 7$ \\
\hline \hline $\begin{array}{c}\text { Evaluation index } \\
\text { Steel yielding }\end{array}$ & 1.18 & 1.33 & 1.56 & 1.72 & 1.78 & 1.81 & 1.92 \\
\hline $\begin{array}{c}\text { Stiffness, E× } \\
\text { Thickness, } \mathrm{t} \\
(\mathrm{kN} / \mathrm{mm})\end{array}$ & 25.53 & 51.06 & 76.59 & 102.75 & 115.52 & 128.28 & 141.05 \\
\hline Beam & $\mathrm{P}$ & $2 \mathrm{P}$ & $3 \mathrm{P}$ & $\mathrm{PC} 7$ & $1.5 \mathrm{PC} 7$ & $2 \mathrm{PC} 7$ & $2.5 \mathrm{PC} 7$ \\
\hline \hline $\begin{array}{c}\text { Evaluation index } \\
\text { Steel yielding }\end{array}$ & 1.16 & 1.43 & 1.52 & 1.61 & 1.75 & 1.85 & 1.87 \\
\hline $\begin{array}{c}\text { Stiffness, E× } \\
\text { Thickness, } \mathrm{t} \\
(\mathrm{kN} / \mathrm{mm})\end{array}$ & 30.72 & 61.44 & 92.16 & 107.94 & 123.30 & 138.66 & 154.02 \\
\hline
\end{tabular}

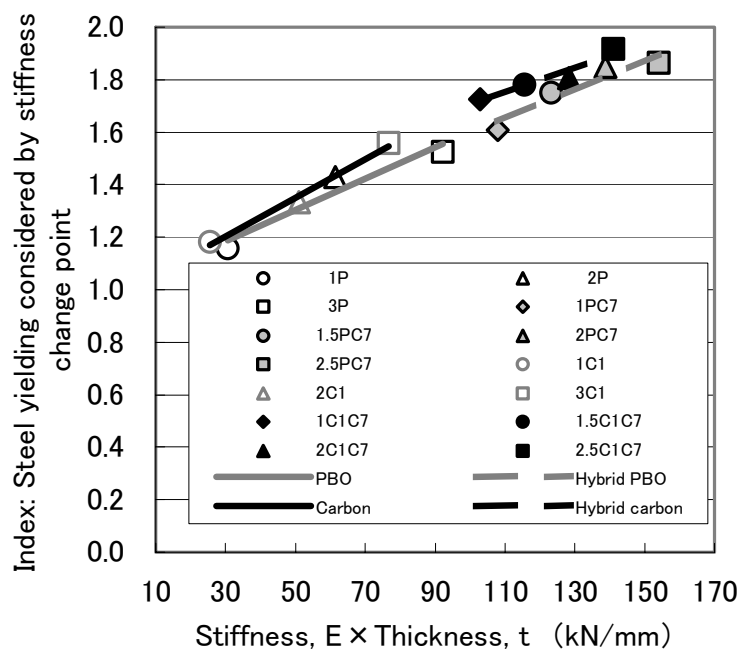

Fig.10 Evaluation index: Steel yielding measured with strain gauges.

a linear relationship between the yielding load and the effective stiffness $\left(E_{t}\right)$ of FRP, although both cases of single types of fibers and hybrid fibers are not in one line. Because the yielding loads of specimens are measurement points of strain gauges attached to the rebars, there is a differencebetween the measurement and the real situation. Therefore, the loads at inflection points deduced from the load-deflection curve are considered here. Due to the use of hybrid fibers, the stiffness level of the RC beams shifted to a higher range $(110-160 \mathrm{kN} / \mathrm{mm})$, but these lines are non-linear between $30-90 \mathrm{kN} / \mathrm{mm}$ and $110-160 \mathrm{kN} / \mathrm{mm}$. It seems that the sites where the strain gauges are adhered are different from the points of partial yielding of steel rebar. In the next section, the steel yielding load is obtained according to the inflection point on the load-displacement curve.

b) Evaluation of the steel yielding load deduced from the inflection point on the load-displacement curve

Table 8 and Fig. 10 show the load at the inflection point versus the stiffness of various FRP sheets. A good linear variation between the individual and the hybrid fibers is demonstrated. Hybrid fiber use
Table 9 Evaluation index: maximum load.

\begin{tabular}{|c|c|c|c|c|c|c|c|}
\hline Beam & $\mathrm{C} 1$ & $2 \mathrm{C} 1$ & $3 \mathrm{C} 1$ & $\mathrm{C} 1 \mathrm{C} 7$ & $1.5 \mathrm{C} 1 \mathrm{C} 7$ & $2 \mathrm{C} 1 \mathrm{C} 7$ & $2.5 \mathrm{C} 1 \mathrm{C} 7$ \\
\hline $\begin{array}{c}\text { Evaluation index } \\
\text { maximum load }\end{array}$ & 1.16 & 1.40 & 1.60 & 1.47 & 1.50 & 1.73 & 1.76 \\
\hline $\begin{array}{c}\text { Stiffness, E× } \\
\text { Thickness, t } \\
(\mathrm{kN} / \mathrm{mm})\end{array}$ & 0.47 & 0.94 & 1.41 & 0.47 & 0.70 & 0.94 & 1.17 \\
\hline Beam & $\mathrm{P}$ & $2 \mathrm{P}$ & $3 \mathrm{P}$ & PC7 & $1.5 \mathrm{PC} 7$ & $2 \mathrm{PC} 7$ & $2.5 \mathrm{PC} 7$ \\
\hline $\begin{array}{l}\text { Evaluation index } \\
\text { maximum load }\end{array}$ & 1.16 & 1.30 & 1.55 & 1.41 & 1.64 & 1.72 & 1.87 \\
\hline $\begin{array}{c}\text { Stiffness, E× } \\
\text { Thickness, } \mathrm{t} \\
(\mathrm{kN} / \mathrm{mm})\end{array}$ & 0.53 & 1.06 & 1.60 & 0.53 & 0.80 & 1.06 & 1.33 \\
\hline
\end{tabular}

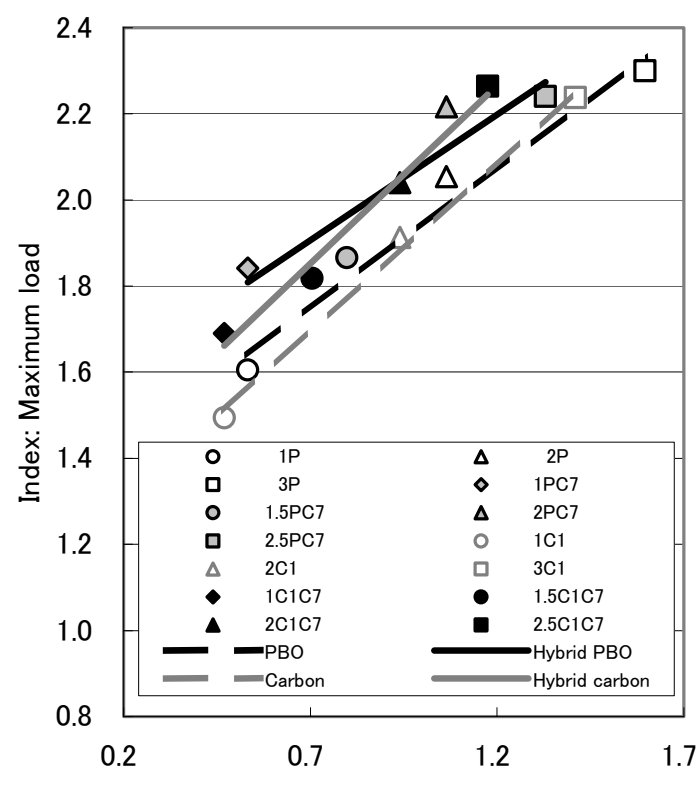

Tensile strength, $f_{p} \times$ Thickness, $t \quad(k N / m m)$ Fig.11 Evaluation index: maximum load.

increases the stiffness level of the RC beams.

c) Evaluation of maximum load

Table 9 and Fig.11 show the relationship between the maximum load and the potential tensile strength of the FRP sheets. The strengthening effect on load-carrying capacity is higher for the hybrid FRP reinforcement than for the FRP sheet with merely single fiber types. Moreover, there is a limit on strength enhancement for single-type fiber sheets due to the limiting characteristics of the FRP-concrete interface.

d) Evaluation of the ductility ratio of beams strengthened with hybrid FRP sheets

Table 10 and Fig.12 show that for all the fibers studied, ductility is large within the range of potential tensile strength values of $0.6-1 \mathrm{kN} / \mathrm{mm}$ and is small for the other ranges.

\section{e) Evaluation of tensile strain of hybrid FRP sheets}

Table 11 and Fig.13 show the relationship between the maximum FRP strain and the potential tensile strength of the FRP sheets. Resistance to FRP 
Table 10 Evaluation index: ductility.

\begin{tabular}{|c|c|c|c|c|c|c|c|}
\hline Beam & $1 \mathrm{C} 1$ & $2 \mathrm{C} 1$ & $3 \mathrm{C} 1$ & $1 \mathrm{C} 1 \mathrm{C} 7$ & $1.5 \mathrm{C} 1 \mathrm{C} 7$ & $2 \mathrm{C} 1 \mathrm{C} 7$ & $2.5 \mathrm{C} 1 \mathrm{C} 7$ \\
\hline \hline $\begin{array}{c}\text { Evaluation index } \\
\text { Ductility }\end{array}$ & 3.67 & 5.01 & 4.09 & 3.34 & 7.88 & 7.13 & 4.55 \\
\hline $\begin{array}{c}\text { Stiffness, Ex } \\
\text { Thickness, t } \\
\text { (kN/mm) }\end{array}$ & 0.47 & 0.94 & 1.41 & 0.47 & 0.70 & 0.94 & 1.17 \\
\hline Beam & $1 \mathrm{P}$ & $2 \mathrm{P}$ & $3 \mathrm{P}$ & $1 \mathrm{PC} 7$ & $1.5 \mathrm{PC} 7$ & $2 \mathrm{PC} 7$ & $2.5 \mathrm{PC} 7$ \\
\hline \hline $\begin{array}{c}\text { Evaluation index } \\
\text { Ductility }\end{array}$ & 5.29 & 6.25 & 3.13 & 4.25 & 5.67 & 5.66 & 5.56 \\
\hline $\begin{array}{c}\text { Stiffness, E× } \\
\text { Thickness, } \mathrm{t} \\
(\mathrm{kN} / \mathrm{mm})\end{array}$ & 0.53 & 1.06 & 1.60 & 0.53 & 0.80 & 1.06 & 1.33 \\
\hline
\end{tabular}

\begin{tabular}{|c|c|c|c|c|c|}
\hline 0 & 1P & $\Delta$ & $2 \mathrm{P}$ & 口 & $3 \mathrm{P}$ \\
\hline$\bullet$ & $1 \mathrm{PC7}$ & 0 & $1.5 \mathrm{PC} 7$ & $\Delta$ & $2 \mathrm{PC7}$ \\
\hline 口 & $2.5 \mathrm{PC} 7$ & 0 & $1 \mathrm{C} 1$ & $\Delta$ & $2 \mathrm{C} 1$ \\
\hline 口 & $3 \mathrm{C} 1$ & $\bullet$ & $1 \mathrm{C} 1 \mathrm{C} 7$ & $\bullet$ & $1.5 \mathrm{C} 1 \mathrm{C} 7$ \\
\hline$\Delta$ & $2 \mathrm{C} 1 \mathrm{C} 7$ & - & $2.5 \mathrm{C} 1 \mathrm{C} 7$ & & PBO \\
\hline & Hybrid PBO & & Carbon & $=$ & Hybrid (Carbon) \\
\hline
\end{tabular}

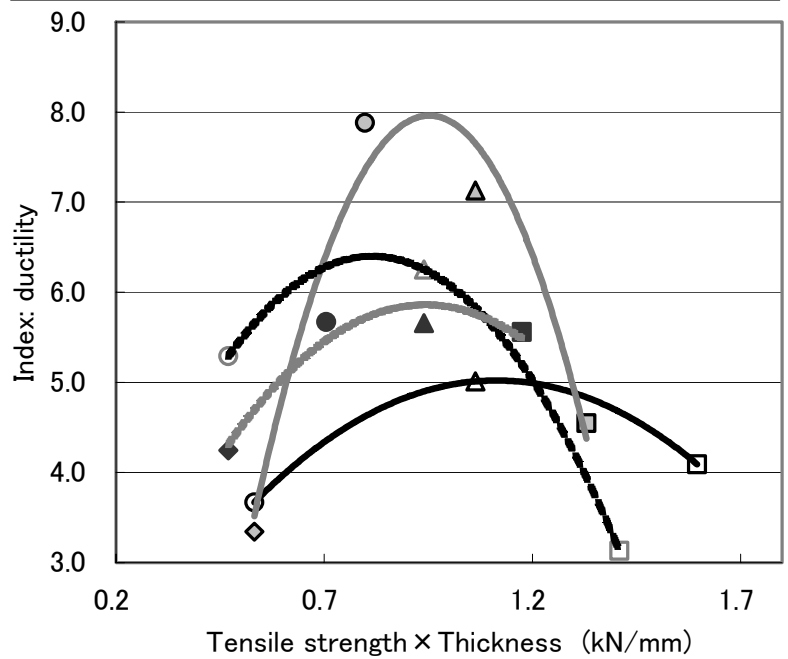

Fig.12 Evaluation index: ductility.

debonding decreases with increasing layers of hybrid fiber sheets.

f) Evaluation of the integrative performance of beams strengthened with hybrid FRP sheets

Integrative indices of all the specimens are shown in Table 12. Those specimens with a failure mode of FRP debonding and partial concrete crushing, such as $2 \mathrm{C} 1 \mathrm{C} 7,2.5 \mathrm{C} 1 \mathrm{C} 7,2 \mathrm{PC} 7$ and $2.5 \mathrm{PC} 7$, show a higher integrative index than those of specimens with a failure mode of FRP rupture or debonding with partial rupture.

\section{CONCLUSIONS}

Based on the experimental investigations, it can be concluded that:

(1) For both FRP and hybrid FRP reinforced specimens, with increased amounts of FRP sheets, the failure model of the strengthened structures shifts from FRP sheet rupture to FRP sheets
Table 11 Evaluation index: maximum FRP strain.

\begin{tabular}{|c|c|c|c|c|c|c|c|}
\hline Beam & $\mathrm{C} 1$ & $2 \mathrm{C} 1$ & $3 \mathrm{C} 1$ & $\mathrm{C} 1 \mathrm{C} 7$ & $1.5 \mathrm{C} 1 \mathrm{C} 7$ & $2 \mathrm{C} 1 \mathrm{C} 7$ & $2.5 \mathrm{C} 1 \mathrm{C} 7$ \\
\hline \hline $\begin{array}{c}\text { Evaluation index } \\
\text { maximum FRP } \\
\text { strain }\end{array}$ & 0.77 & 0.72 & 0.60 & 0.98 & 0.95 & 0.84 & 0.72 \\
\hline $\begin{array}{c}\text { Stiffness, E× } \\
\text { Thickness, } \mathrm{t} \\
\text { (kN/mm) }\end{array}$ & 0.47 & 0.94 & 1.41 & 0.47 & 0.70 & 0.94 & 1.17 \\
\hline Beam & $\mathrm{P}$ & $2 \mathrm{P}$ & $3 \mathrm{P}$ & $\mathrm{PC7}$ & $1.5 \mathrm{PC} 7$ & $2 \mathrm{PC} 7$ & $2.5 \mathrm{PC} 7$ \\
\hline \hline $\begin{array}{c}\text { Evaluation index } \\
\text { maximum FRP } \\
\text { strain }\end{array}$ & 0.75 & 0.94 & 0.49 & 1.11 & 0.91 & 1.06 & 0.78 \\
\hline $\begin{array}{c}\text { Stiffness, Ex } \\
\text { Thickness, } \mathrm{t} \\
(\mathrm{kN} / \mathrm{mm})\end{array}$ & 0.53 & 1.06 & 1.60 & 0.53 & 0.80 & 1.06 & 1.33 \\
\hline
\end{tabular}

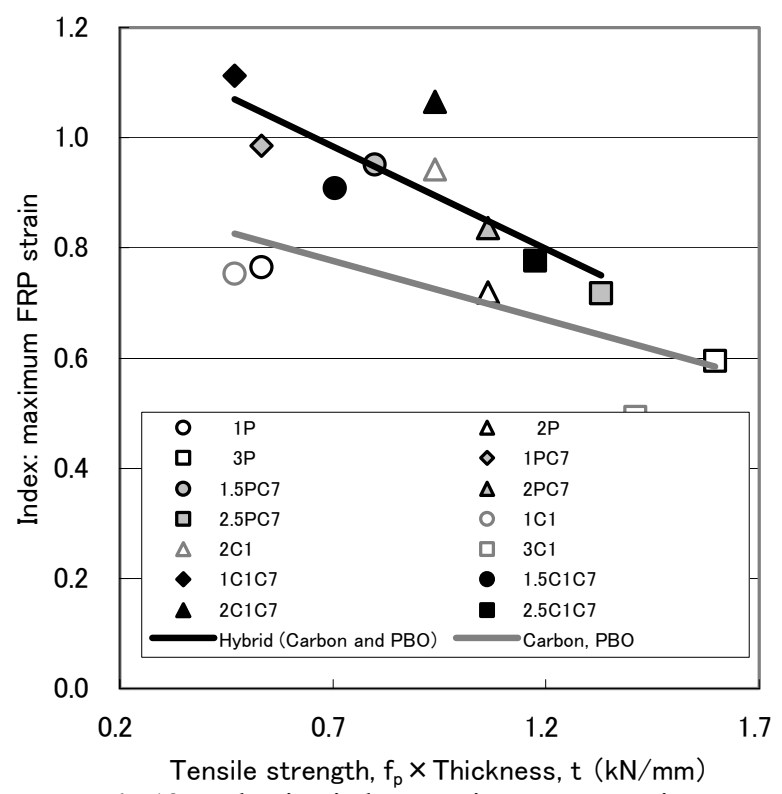

Fig.13 Evaluation index: maximum FRP strain.

Table 12 Total evaluation.

\begin{tabular}{|c|c|c|c|}
\hline \multirow{2}{*}{ Beams } & \multicolumn{3}{|c|}{ Index } \\
\cline { 2 - 4 } & $\begin{array}{c}\text { Steel yielding } \\
\text { load }\end{array}$ & $\begin{array}{c}\text { Maximum } \\
\text { load }\end{array}$ & FRP strain \\
\hline \hline $1 \mathrm{C} 1$ & 1.18 & 1.49 & 0.75 \\
\hline $2 \mathrm{C} 1$ & 1.33 & 1.91 & 0.94 \\
\hline $3 \mathrm{C} 1$ & 1.56 & 2.24 & 0.49 \\
\hline $1 \mathrm{C} 1 \mathrm{C} 7$ & 1.72 & 1.69 & 1.11 \\
\hline $1.5 \mathrm{C} 1 \mathrm{C} 7$ & 1.78 & 1.82 & 0.91 \\
\hline $2 \mathrm{C} 1 \mathrm{C} 7$ & 1.81 & 2.04 & 1.06 \\
\hline $2.5 \mathrm{C} 1 \mathrm{C} 7$ & 1.92 & 2.26 & 0.78 \\
\hline $1 \mathrm{P}$ & 1.16 & 1.60 & 0.77 \\
\hline $2 \mathrm{P}$ & 1.43 & 2.05 & 0.72 \\
\hline $3 \mathrm{P}$ & 1.52 & 2.30 & 0.60 \\
\hline $1 \mathrm{PC} 7$ & 1.61 & 1.84 & 0.98 \\
\hline $1.5 \mathrm{PC} 7$ & 1.75 & 1.87 & 0.95 \\
\hline $2 \mathrm{PC} 7$ & 1.85 & 2.22 & 0.84 \\
\hline $2.5 \mathrm{PC} 7$ & 1.87 & 2.24 & 0.72 \\
\hline
\end{tabular}


debonding from concrete structures or concrete crushing. At the same time, the hybrid indices, including steel yielding load, maximum load and ductility, increase.

(2) An index to control the load drop is proposed, and the relationship between it and the composition of hybrid FRP sheets is experimentally investigated. It is shown that the load drop due to the fracture of high modulus fibers can be well suppressed through increasing the volume fraction of high strength fibers in the hybrid FRP sheets.

(3) Provided that the amount of fiber sheets as reinforcements is the same, the strengthening effect of hybrid FRP sheets is better than that of FRP sheets of single fibers. For the specimens strengthened with hybrid FRP sheets, the crack width is relatively small, the concrete cracks distribute more dispersively and the propagation of cracks is effectively suppressed.

(4) The ductility is larger within the range of potential tensile strength values of $0.6-1 \mathrm{kN} / \mathrm{mm}$ and smaller in the other ranges. The usage of PBO fiber sheet with its excellent energy absorbing capacity can markedly increase the ductility and decrease the value of the load drop.

(5) The maximum loads of concrete beams strengthened with hybrid FRP sheets are somewhat bigger than those of concrete beams strengthened with FRP sheets with a single type of fibers under the same strengthening condi- tions.

ACKNOWLEDGMENT: The authors would like to gratefully acknowledge Toyobo Co. Ltd. for providing the $\mathrm{PBO}$ fiber sheets.

\section{REFERENCES}

1) Wu, Z. S., Sakamoto, K., Iwashita, K. and Yue, Q. : Hybridization of continuous fiber sheets as structural composites, Journal of the Japan Society for Composite Materials, Vol.32, No.1, pp.12-21, 2006.

2) Hull, D. and Clyne, T. W. : An introduction to Composite Materials, Second edition, Syndicate of the Cambridge University Press, England, 1996.

3) JSCE: Standard Specifications for Design and Construction of Concrete Structures (Design), 1996.

4) JSCE: Recommendations for Upgrading of Concrete Structures with Use of Continuous Fiber Sheets, Concrete Engineering Series 41, 2001.

5) Yoshizawa, H. and $\mathrm{Wu}$, Z. S. : Experimental Study on Crack Behavior of RC Tensile Members Strengthened with Carbon Fiber Sheets, Journal of Materials, Concrete Structures and Pavement, JSCE, No.613/V-42, pp.249-262, 1999.

6) Wu, Z.S., Sakamoto, K., Niu, H. D., Shimada, M. and Murakami, S. : Strengthening effect of concrete flexural members retrofitted with hybrid FRP composites, Proc. of the third international conference on composites in infrastructure (ICCI'04), CD-ROM, California, USA, 2002

(Received February 5, 2007) 